\title{
I WANT TO HAVE WHAT YOU HAVE AND I DO NOT WANT YOU TO HAVE IT
}

\author{
Agata BŁACHNIO ${ }^{1}$, Aneta PRZEPIORKA \\ ${ }^{1}$ Institute of Psychology, The John Paul II Catholic University of Lublin \\ Al. Racławickie 14, 20-950 Lublin, Poland \\ E-mail: gatta@kul.pl, aneta.przepiorka@gmail.com
}

\begin{abstract}
Envy is the emotion felt towards another person when they have something that one wants to have or a wish that they did not have it. Some authors distinguish malicious and benign forms of envy. The main aim of the presented research was to examine whether envy is related to self-esteem, Schadenfreude, optimism, and rumination. Additionally, the aim was to verify the validity and reliability of the Polish version of the Dispositional Envy Scale (DES), measuring the tendency to feel envy that is close to malicious envy. The participants were 1,221 people aged from 14 to 69 . The DES was translated into Polish using the back-translation procedure. The 8item one-factor DES has good psychometric properties, with a Cronbach's alpha of .86. The findings show that envy is positively related to Schadenfreude and rumination and negatively to age, self-esteem, and optimism.
\end{abstract}

Key words: envy, Schadenfreude, self-esteem, rumination, optimism

\section{Introduction}

When your neighbor owns a better car or a bigger house, when your classmate receives a better grade, or when your colleague sitting at the desk next to you has been promoted, you may feel envious. Material goods, social position, physical appearance, competence, skills, or even psychological state can become an object of envy (Miceli \& Castelfranchi, 2007). Envy occurs in any situation when one makes an upward comparison with another and perceives others as being more fortunate than one is (van de Ven, Zeelenberg, \& Pieters, 2009). The feeling of envy is a tendency present in all cultures, and in almost all languages there is a word for this phenomenon (Smith, Parrott, Diener, Hoyle, \& Kim, 1999). Although envy has been an issue of philosophical or religious debate for a long time, psychological research on envy is scarce, and, considering the impact of envy on social life, this emotion should be investigated more thoroughly (Miceli \& Castelfranchi, 2007). To fill this gap as well as to learn more about envy and particular dispositions related to it, the present study examined whether envy is related to positive dispositions such as self-esteem and optimism and to the tendency to ruminate. Additionally, the study was to validate the Polish version of the Dispositional Envy Scale(DES).

In the literature, dispositional and episodic envy can be distinguished (Cohen-Charash, 2009). The first is a permanent, and chronic individual difference variable. In other words, it is a general tendency to feel envy (Smith et al., 1999). By contrast, episodic envy can be

DOI: $10.21909 /$ sp.2015.04.697 
felt by everybody as a result of negative social comparison and consists of two components: negative emotional feelings and negative comparisons (Cohen-Charash, 2009). It has been suggested that there are two distinct forms of envy. Van de Ven et al. (2009) tested the distinction between two types of envy: benign and malicious, assumed to be quantitatively different. Malicious envy is defined as related to the motivation to harm the position of a superior other. This feeling is hostile and consists in a desire to damage the position of the envied person. Benign envy is connected with improving oneself by moving upward. This form of envy appears when the envied person has something that one desires and involves effort aimed at improving oneselfbut not meant to destroy the other person (Crusius \& Lange, 2014). These two emotional experiences have opposite outcomes. A person feeling benign envy is motivated to improve their situation (moving-up motivation), while in case of malicious envy the motivation is to do harm to the envied person (pulling-down motivation) (van de Ven et al., 2009). Some results indicate that the DES measures malicious rather than benign envy (Lange \& Crusius, 2015).

\section{Envy and Jealousy}

In the literature, envy has been defined as a hostile emotional reaction and a mixture of different emotions that comprises hostility, resentment, as well as feelings of inferiority, and injustice (Smith \& Kim, 2007). This feeling is caused by the belief that other people have something (a thing, social position, a trait) that one does not have and a longing to have it or a wish that the other person did not have it either (Parrott, 1991). Silver and
Sabini (1978) highlighted two different meanings of the term "envy", depending on the context. It can either convey a compliment or praise (That's so wonderful, I envy you! p. 106) or function in a negative way.

In everyday language, envy is often wrongly used interchangeably with jealousy. However, there is a clear distinction between these two emotions (Parrott \& Smith, 1993). Envy arises in situations when one lacks some attribute or value that another person is in possession of; in the case of jealousy, one is afraid of losing one's partner to a rival (Smith \& Kim, 2007). Parrott and Smith (1993) examined the emotional experiences of envy and jealousy. Envy was found to comprise longing, disapproval of feelings, motivation to improve, whereas distrust, fear, uncertainty, and loneliness were found to constitute the experience of jealousy. Another difference was in intensity, with jealousy being more intense than envy. The authors also claim that two elements are required to experience envy while three of them are needed to be jealous, and that these elements do not have to be human beings. They also found that the feeling of jealousy is, in most cases, accompanied by the feeling of envy. You may envy your rival, to whom you are afraid of losing your partner, some attributes or social position. There is also a difference in term coverage: while the term jealousy can mean either envy or jealousy, envy refers only to envy. Envy is perceived as less socially acceptable. Envy is a social emotion; it is more often felt towards a stranger and rarely or less intensely towards a close other (Piskorz \& Piskorz, 2009). Both emotions are related to another person. Jealousy involves three elements: the person experiencing it, the partner, and the rival who can be the potential cause of losing the partner. Envy, by 
contrast, involves two elements: the jealous individual and the person who is judged by that individual to be better (Parrott \& Smith, 1993).

\section{Correlates of Envy}

As indicated by previous studies, envy correlates with other psychological traits (a summary of the findings is presented in Table 1). Envy is positively correlated with depression (Smith et al., 1999; Cohen-Charash, 2009), narcissism (Krizan \& Johar, 2012), Machiavellianism (Vecchio, 2005), and low level of self-esteem (Vecchio, 2005; Smith et al., 1999). Moreover, envy is negatively related to happiness and life-satisfaction (Smith et al., 1999; Milfont \& Gouveia, 2009). Additionally, envy is positively related to hope for success and benign envy and negatively to malicious envy. Malicious envy correlates positively with fear of failure (Lange \& Crusius, 2015). Social injustice and undeservingness are predictors of envy (Feather \& Nairn, 2005; Smith, Parrott, Ozer, \& Moniz, 1994): envy is even greater when the advantage is not deserved.

Recent findings showed that envy was connected with Schadenfreude (van de Ven et al., 2015; Sawada \& Hayama, 2012; Feather \& Sherman, 2002). Interestingly, van de Ven et al. (2015) found that only malicious envy was associated with Schadenfreude, while benign envy was not. Some evidence indicates that envy can be a predictor of Schadenfreude (Sawada \& Hayama, 2012). Other studies show that Schadenfreude pleasure derived from someone else's misfortune - is predicted by resentment, not by envy (Feather \& Sherman, 2002). Van Dijk, Ouwerkerk, Goslinga, Nieweg, and Gallucci (2006) delivered supplementary explanations for the above results. In their study, envy predicted Schadenfreude in a situation when there was a similarity between the target of Schadenfreude and the envying person (in this case, when the two were of the same gender; this effect was not found when the target of Schadenfreude and the envying person were of different genders).

\section{Self-Beliefs and Rumination and Their Relation to Envy}

One of the distinctive characteristics of envy is the feeling of inferiority (see Smith \& Kim, 2007); therefore, in the present study we have concentrated on positive self-beliefs about one's life. Optimism and self-esteem are those positive self-beliefs through which a person perceives the outer world and explains the events that happen in the outer world (Scheier, Carver, \& Bridges, 1994). A large body of research highlights the contribution of optimism to well-being (e.g., Caprara, Steca, \& Caprara, 2007). Since optimism is a disposition that consists in expecting the best and viewing the actual situation in a positive light, it would be interesting to explore whether it is associated with envy, which is usually associated with discontentment, depressive states (Smith et al., 1994), dissatisfaction with the current situation, and complaining about undeserved inferiority (Ben-Ze'ev, 1992). Optimism is related to belief in just world (Lerner, 1980), whereas one of the components of envy is the totally opposite conviction, namely the feeling of injustice (Smith et al., 1994). Positive expectations about one's future and higher self-esteem may be related to lower disposition to envy. Those self-beliefs may both buffer negative comparisons and make people perceive their life as valuable and 
Table 1 The psychological traits correlated with envy

\begin{tabular}{|c|c|c|c|c|}
\hline Authors & Envy measure & Country & Sample & Findings \\
\hline $\begin{array}{l}\text { (Duffy et al., } \\
2012 \text { ) }\end{array}$ & $\begin{array}{l}\text { Vecchio's } \\
\text { 5-item scale }\end{array}$ & USA & 160 employees & $\begin{array}{l}\text { In the group of employees } \\
\text { with a low level of social } \\
\text { identification the mediated } \\
\text { effect of envy on social } \\
\text { undermining behavior } \\
\text { through moral } \\
\text { disengagement is stronger. }\end{array}$ \\
\hline $\begin{array}{l}\text { (Smith et al., } \\
\text { 1999) }\end{array}$ & 8-item DES & USA & $\begin{array}{l}136,65,143, \text { and } \\
206 \text { undergraduates }\end{array}$ & $\begin{array}{l}\text { Envy positively correlates } \\
\text { with depression, } \\
\text { neuroticism, hostility, and } \\
\text { resentment and negatively } \\
\text { with self-esteem, life } \\
\text { satisfaction, happiness, and } \\
\text { jealously. }\end{array}$ \\
\hline $\begin{array}{l}\text { (Krizan and } \\
\text { Johar, 2012) }\end{array}$ & 8-item DES & USA & about 300 adults & $\begin{array}{l}\text { Envy is a central emotion } \\
\text { in narcissistic people. }\end{array}$ \\
\hline (Vecchio, 2005) & 5-item scale & USA & $\begin{array}{l}222 \text { participants in } \\
\text { a program for first- } \\
\text { level supervisors }\end{array}$ & $\begin{array}{l}\text { In work situations envy is } \\
\text { associated with self- } \\
\text { esteem, Machiavellianism, } \\
\text { and job dissatisfaction. }\end{array}$ \\
\hline $\begin{array}{l}\text { (Green et al., } \\
\text { 2014) }\end{array}$ & $\begin{array}{l}\text { 5-item scale } \\
\text { (Belk, 1984) }\end{array}$ & USA & $\begin{array}{l}248 \text { participants } \\
\text { from institutions of } \\
\text { higher learning }\end{array}$ & $\begin{array}{l}\text { Envy is positively } \\
\text { correlated with } \\
\text { materialistic values. }\end{array}$ \\
\hline $\begin{array}{l}\text { (Cohen-Charash, } \\
\text { 2009) }\end{array}$ & $\begin{array}{l}\text { Episodic Envy } \\
\text { Scale, DES, and } \\
\text { Vecchio's Scale }\end{array}$ & USA & $\begin{array}{l}200 \text { employed } \\
\text { individuals }\end{array}$ & $\begin{array}{l}\text { Envy is related to anxiety, } \\
\text { depression, and negative } \\
\text { mood. }\end{array}$ \\
\hline $\begin{array}{l}\text { (Sawada and } \\
\text { Hayama, 2012) }\end{array}$ & $\begin{array}{l}\text { Envy and } \\
\text { Schadenfreude } \\
\text { scenarios }\end{array}$ & Japan & $\begin{array}{l}523 \text { undergraduate } \\
\text { and postgraduate } \\
\text { students }\end{array}$ & $\begin{array}{l}\text { Envy and vengeance are } \\
\text { predictors of } \\
\text { Schadenfreude. }\end{array}$ \\
\hline $\begin{array}{l}\text { (Milfont and } \\
\text { Gouveia, 2009) }\end{array}$ & 8-item DES & Brazil & $\begin{array}{l}102 \text { undergraduate } \\
\text { students }\end{array}$ & $\begin{array}{l}\text { Negative correlation of } \\
\text { envy with happiness, } \\
\text { vitality, and life } \\
\text { satisfaction. }\end{array}$ \\
\hline $\begin{array}{l}\text { (Lange and } \\
\text { Crusius, 2015) }\end{array}$ & $\begin{array}{l}10 \text {-items The } \\
\text { Benign and } \\
\text { Malicious Envy } \\
\text { Scale }\end{array}$ & Germany & 192 participants & $\begin{array}{l}\text { Benign envy related } \\
\text { positively with hope for } \\
\text { success. Malicious envy } \\
\text { related negatively with } \\
\text { hope for success and } \\
\text { positively with fear of } \\
\text { failure. }\end{array}$ \\
\hline
\end{tabular}


positive. A previous study suggested a relationship between envy and self-esteem (Appel, Crusius, \& Gerlach, 2015). Together, this evidence points to the possibility that envy is negatively related to optimism and self-esteem.

As Martin and Tesser (1996) show, the unattainability of some goals may be a source of ruminative states in a person. Rumination means persistent thinking about one's problem and not attempting to cope with the stressful situation (NolenHoeksema, Wisco, \& Lyubomirsky, 2008; Nolen-Hoeksema et al., 2008): the person focuses on themselves and their negative mood (Lyubomirsky \& Nolen-Hoeksema, 1993). Those who have a tendency for ruminative thoughts are not well capable of finding the strategy for solving their problem and improving their mood (NolenHoeksema, 1991). Rumination is considered to be a maladaptive strategy when a person focuses on their disadvantageous situation and is not able to achieve the desired standard (Carver \& Scheier, 1981). The fact that others have achieved more than one has achieved may stir frustration and negative feelings such as envy. Uphill and Dray (2009) suggested that counterfactual thinking was related to rumination - and there is some evidence pointing to a relationship between envy and counterfactual thinking (van de Ven \& Zeelenberg, 2015). Additionally, it should also be considered that envy has implications for cognitive processes and that it is related to the memory and attention of the envier (Hill, DelPriore, \& Vaughan, 2011).

On the basis of these findings, we hypothesized that envy is positively related to rumination. As Miceli and Castelfranchi claimed, one of the components of envy is "helplessness and hopelessness with regard to overcoming one's own inferiority" (p. 470). The person with a higher disposition to envy will also ruminate more often over negative emotional states and their less fortunate life situation.

\section{Envy Measurement}

There are a few methods measuring envy. There is a 5-item measure available in the literature (Vecchio, 2005) that measures envy towards others in the work environment, with items such as: Most of my coworkers have it better than I do. Vecchio (2005) also developed an instrument measuring two aspects of the phenomenon: being envied and envying others (Vecchio, 2005). Furthermore, there is the Envy subscale, which is a part of Belk's (1984) Materialism Scale (e.g., I am bothered when I see people who buy anything they want). Lange \& Crusius (2015) created the Benign and Malicious Envy Scale, containing two factors: benign envy (e.g., Envying others motivates me to accomplish my goals) and malicious envy (e.g., I wish that superior people lose their advantage) measuring two forms of envy.

Indirect methods connected with envy were also used (Habimana \& Massé, 2000). Situations describing envy are employed in envy assessment as well, such as a description of success of a distant or close acquaintance with or without injustice (Your friend - although all his life he made fun of people playing number games - decided to play once for fun and won big amounts of money) (Piskorz \& Piskorz, 2009). The most popular and the most often used instrument is the one-factor Dispositional Envy Scale (DES), measuring individuals' tendency to feel envy, developed by Smith et al. (1999). The Brazil- 
ian-Portuguese adaptation of the DES was developed by Milfont and Gouveia (2009). There is also a children's version of this scale (Sawada \& Arai, 2002). To our best knowledge, there is no Polish adaptation of this scale; therefore, a study was conducted in order to examine the psychometric properties of the DES.

\section{Method}

\section{Participants}

A sample of 1,221 individuals took part in the study, $65 \%$ of the participants being female. Their mean age was 21.54 years $(S D=$ 4.37 , range from 14 to 69 years). Almost $70 \%$ were students, about $18 \%$ were studying and working people, $8 \%$ were working people, and the rest were unemployed and temporarily employed. Demographic questions were used to collect data about gender and age. The participants completed a self-report booklet containing four questionnaires. A simple random sampling procedure was used to recruit participants. Participation in the study was voluntary, and all the procedures conformed to institutional ethical guidelines for research.

\section{Measures}

Envy was measured using the Dispositional Envy Scale (Smith et al., 1999). This instrument measures a permanent tendency to feel envy and consists of eight items, for instance: I feel envy every day. Responses to the items are given on a 5-point Likerttype scale. The back-translation procedure was used in adapting the DES from English. Cronbach's alpha was found to be .86 for the Polish version of the scale.
Self-esteem was assessed using Rosenberg's Self-Esteem Scale as adapted into Polish byŁaguna, Lachowicz-Tabaczek, and Dzwonkowska (2007). It is a 10-item scale related to the overall feeling of self-worth. Responses were given on a scale from 1 (strongly disagree) to 4 (strongly agree).

An alternative method of measuring envy was also used - namely, Envy and Schadenfreude Scenarios (Sawada \& Hayama, 2012), in which participants read two scenarios that triggered first envy and then Schadenfreude. After that, the participants assessed their feeling on several dimensions such as Ifeel inferior or Ifeel happy. The Polish version is in preparation, and in this study we used an experimental version of this method.

Rumination was measured with Drwal's Polish version of Caprara's (1986) Dissipation-Rumination Scale (DRS). It consists of 20 items and responses are given on a 5point Likert-type self-report scale.

To measure optimism, we used the Revised Life Orientation Test (LOT-R; (Juczyński, 1999). It measures the level of dispositional optimism and consists of 10 items. Responses are given on a 5-point scale. Cronbach's alpha for this scale was .69.

\section{Results}

\section{Reliability Findings}

The value of Cronbach's alpha was .86 and was similar to that in the original version. The internal validity of the Polish version of the scale was acceptable. Table 2 shows the means for items (ranging from 1.38 to 2.56), standard deviations, and item-total correlations (ranging from .65 to .76). The exploratory analysis performed using the principal components method with varimax orthogo- 
nal rotation indicated that the one-factor solution adopted is acceptable and explains $51 \%$ of variance; factor loadings ranged from -.65 to -.75 .

The one-factor model was quite well fitted and all the indices were acceptable. As regards the model's goodness of fit, the root mean square error of approximation (RMSEA) was .066, GFI was .981, the PRATIO coefficient was .536, RMR was .039, and the HOETLER index was 393.

\section{Validity Findings}

In the next stage of the study, we checked the criterion validity of the measure by ana-

Table 2 Means of Items (M), Standard Deviations (SD), Item-total Correlations (ITC), and Factor Loadings for the Polish Version of the DES from Exploratory Factor Analysis (EFA) and Confirmatory Factor Analysis (CFA)

\begin{tabular}{|c|c|c|c|c|c|}
\hline Items & $M$ & $S D$ & ITC & $\begin{array}{c}\text { EFA } \\
\text { loadings }\end{array}$ & $\begin{array}{c}\text { CFA } \\
\text { loadings }\end{array}$ \\
\hline \multirow{2}{*}{$\begin{array}{l}\text { 1. I feel envy every day. } \\
\text { Czuje zawiść każdego dnia. } \\
\text { 2. The bitter truth is that I generally feel } \\
\text { inferior to others. } \\
\text { Gorzka prawda jest taka, że czuję się } \\
\text { ogólnie gorszy(a) od innych. }\end{array}$} & 1.63 & 0.96 & $.67 * * *$ & -.69 & .54 \\
\hline & 2.19 & 1.22 & $.74 * * *$ & -.73 & .62 \\
\hline $\begin{array}{l}\text { 3. Feelings of envy constantly torment me. } \\
\text { Uczucie zawiści ciagle mnie męczy. }\end{array}$ & 1.72 & 1.14 & $.65^{* * *}$ & -.65 & .47 \\
\hline $\begin{array}{l}\text { 4. It is so frustrating to see some people } \\
\text { succeed so easily. } \\
\text { Frustruje mnie widok ludzi odnoszacych z } \\
\text { taka tatwościa sukces. }\end{array}$ & 2.25 & 1.25 & $.76^{* * *}$ & -.75 & .76 \\
\hline $\begin{array}{l}\text { 5. No matter what I do, envy always plagues } \\
\text { me. } \\
\text { Cokolwiek robię, zawiść ciagle mnie } \\
\text { dręczy. }\end{array}$ & 1.38 & 0.81 & $.72 * * *$ & -.75 & .61 \\
\hline $\begin{array}{l}\text { 6. I am troubled by feelings of inadequacy. } \\
\text { Martwię się, ze jestem niedoskonaty }(a) \text {. }\end{array}$ & 2.56 & 1.32 & $.70 * * *$ & -.67 & .55 \\
\hline $\begin{array}{l}\text { 7. It somehow doesn't seem fair that some } \\
\text { people seem to have all the talent. } \\
\text { Niesprawiedliwe jest, że inni ludzie wydaja } \\
\text { się mieć talent do wszystkiego. }\end{array}$ & 2.25 & 1.32 & $.76^{* * *}$ & -.74 & .73 \\
\hline \multirow{2}{*}{$\begin{array}{l}\text { 8. Frankly, the success of my neighbors } \\
\text { makes me resent them. } \\
\text { Szczerze mówiac, sukces osób z mojego } \\
\text { otoczenia napawa mnie negatywnymi } \\
\text { emocjami wobec nich. }\end{array}$} & & & & & \\
\hline & 1.61 & 0.96 & $.70^{* * *}$ & -.72 & .71 \\
\hline
\end{tabular}


Table 3 Correlations of the Dispositional Envy Scale with Self-esteem, Schadenfreude and Envy Scale, Optimism, Rumination, and Age

\begin{tabular}{lccc}
\hline Variables & Measure & $N$ & Pearson's $r$ \\
\hline Self-esteem & Rosenberg's Self-Esteem Scale & 1218 & $-.46^{* * *}$ \\
Envy (situations) & Schadenfreude and Envy Scale by Sawada and Hayama & 1218 & $.55^{* * *}$ \\
Schadenfreude & Schadenfreude and Envy Scale by Sawada and Hayama & 1218 & $.17^{* * *}$ \\
Optimism & Revised Life Orientation Scale & 99 & $-.26^{* *}$ \\
Rumination & Dissipation-Rumination Scale & 99 & $.40^{* * *}$ \\
Age & - & 1218 & $-.07 *$ \\
\hline$* p<.05,{ }^{* *} p<.01,{ }^{* * *} p<.001$ & &
\end{tabular}

lyzing the correlations between envy and other variables, such as: self-esteem, envy measured using the narrative method, Schadenfreude, optimism, rumination, and age. Envy correlated positively with envy measured using the narrative method. It correlated negatively with self-esteem, optimism, and age (see Table 3).

\section{Discussion}

The aim of this study was to examine whether envy is associated with Schadenfreude, optimism, self-esteem, and rumination and to adapt a self-report instrument, the Dispositional Envy Scale (DES), into Polish. In order to test the psychometric properties of the DES, factor analysis was performed and one factor was extracted from the 8-item questionnaire. The scale showed good internal consistency. The factor explained $51 \%$ of the variance. In this study, we showed that the Polish version of the DES is a reliable instrument for assessing envy. Additionally, the results of this study indicate that envy correlates quite strongly with self-beliefs (such as self-esteem) or with optimism as well as with rumination and Schadenfreude, and that its relationship with age is rather weak.
As predicted, the lower the level of selfesteem, the stronger the tendency to feel envy. This finding in the present study is consistent with the finding obtained in a German sample (Appel et al., 2015) or in an American sample (Smith et al., 1999). Regarding the association between envy and optimism, there was a significant negative correlation, which implies that those who are low on optimism have a tendency to be envious of others. Similarly, previous studies have shown that envy is negatively linked with happiness and satisfaction with life (Milfont \& Gouveia, 2009). In the current study, the strong and significant positive correlation between envy and Schadenfreude supports Krizan and Johar' study (2012), which yielded similar results. There is also evidence that envy is a predictor of Schadenfreude: the stronger tendency a person has to feel envy, the more they feel Schadenfreude (Sawada \& Hayama, 2012). Envy correlated positively with rumination. The more often people feel envy, the stronger tendency they have to ruminate. According to a previous study, rumination increases the negative emotion ruminated on (McCullough, Bono, \& Root, 2007). Thus, it is possible that ruminating on envy strengthens this emotion. 
A negative relationship was found between age and envy, though the correlation was weak. The tendency for being envious decreases with age, which is in concordance with the study by Harris and Henniger (2013). Moreover, this result seems to be consistent with evidence pertaining to the tendency of general negative affect to decrease with age (Ready et al., 2011; Harris \& Henniger, 2013). Finally, dispositional envy correlated positively with envy measured using other instruments designed to measure envy, which supports the criterion validity of the DES.

\section{Limitations}

There are some limitations to our findings. First of all, the data are self-reported and prone to many confounding factors such as social desirability. Another factor is a distortion of memory that may have occurred while the participants were recalling the episodes of envy. As regards the mean age $(M=21.54$ years), a majority of the participants were students. The sample was not equal in terms of gender representation, either: the majority were women. One of the advantages of this study is online recruitment using the snowball sampling technique. The participants recruited further subjects from among their acquaintances. On the one hand, this method gave us access to a wider range of participants, but, on the other, a majority of the participants were of the same age. Considering the correlational character of this study, conclusions about the causal relationship between the envy and individual characteristics cannot be drawn.

Despite those limitations, the current study contributes to the not particularly extensive literature on envy. To sum up, the overall findings show that the Polish adaptation of the DES can be considered a useful practical tool for assessing disposition for envy. What this study adds to the recent research on envy is that those who have a disposition to be envious also have a tendency to feel Schadenfreude and to ruminate; they are low on self-esteem and optimism, too. This disposition decreases with age. In the future, it would be advisable to conduct a similar study among children and elderly people. It may be interesting to find out when envy appears and how it changes in the course of human life. More research on envy in different countries is also needed to provide a better understanding of this phenomenon. It could help to better explain the determinants of envy. The identification of more variables explaining envy could be helpful in creating a model showing the mechanism of experiencing this emotion. Clearly, such investigations would increase the knowledge on envy and translate it into practice.

\section{Conclusions}

To sum up, the current study makes two important contributions. First, it corroborates and extends the findings of previous research on the correlates of envy; second, it has adapted the scale for measuring envy into Polish. The Polish version of the 8-item one-factor Dispositional Envy Scale has been presented and has good psychometric properties. Additionally, we found that envy is positively related to Schadenfreude and rumination and negatively related to age, selfesteem, and optimism. In conclusion, to our knowledge, this is the first study that shows the association between envy, rumination, and optimism.

Received September 22, 2014 


\section{References}

Appel, H., Crusius, J., \& Gerlach, A. L. (2015). Social comparison, envy, and depression on Facebook: A study looking at the effects of high comparison standards on depressed individuals. Journal of Social and Clinical Psychology, 34(4), 277-289. doi:10.1521/jscp.2015.34.4.277

Ben-Ze'ev, A. (1992). Envy and inequality. Journal of Philosophy, 89, 551-581.

Caprara, G. V. (1986). Indicators of aggression: The Dissipation-Rumination Scale. Personality and Individual Differences, 7(6), 763-769. doi:10. 1016/0191-8869(86)90074-7

Caprara, M., Steca, P., \& Caprara, G. V. (2007). Personality and self-beliefs. In R. FernándezBallesteros (Ed.), Geropsychology: European perspectives for an aging world (pp. 103-127). Ashland, OH, US: Hogrefe \& Huber Publishers.

Carver, C. S., \& Scheier, M. F. (1981). Attention and self-regulation. Springer.

Cohen-Charash, Y. (2009). Episodic envy. Journal of Applied Social Psychology, 39(9), 2128-2173. doi:10.1111/j.1559-1816.2009.00519.x

Crusius, J., \& Lange, J. (2014). What catches the envious eye? Attentional biases within malicious and benign envy. Journal of Experimental Social Psychology, 55, 1-11. doi:10.1016/j.jesp.2014 05.007

Dijk, W. W. Van, Ouwerkerk, J. W., Goslinga, S., Nieweg, M., \& Gallucci, M. (2006). When people fall from grace: Reconsidering the role of envy in Schadenfreude, 6(1), 156-160. doi:10.1037 1528-3542.6.1.156

Feather, N., \& Nairn, K. (2005). Resentment, envy, Schadenfreude, and sympathy: Effects of own and other's deserved or undeserved status. Australian Journal of Psychology, 57(2), 87-102. doi:10.1080/00049530500048672

Feather, N. T., \& Sherman, R. (2002). Envy, resentment, Schadenfreude, and sympathy: Reactions to deserved and undeserved achievement and subsequent failure. Personality and Social Psychology Bulletin, 28(7), 953-961. doi:10. $1177 / 01467202028007008$

Habimana, E., \& Massé, L. (2000). Envy manifestations and personality disorders. European Psychiatry, 15(Suppl 1), 15-21. doi:10.1016/S09249338(00)00501-0

Harris, C. R., \& Henniger, N. E. (2013). Envy, politics, and age. Frontiers in Psychology, 4. Retrieved from http://search.ebscohost.com/login. aspx direct $=$ true $\& d b=$ psyh $\& A N=2013-16024-$ $001 \&$ site $=$ ehost-live

Hill, S. E., DelPriore, D. J., \& Vaughan, P. W. (2011). The cognitive consequences of envy: Attention, memory, and self-regulatory depletion. Journal of Personality and Social Psychology, 101(4), 653-666. doi:10.1037/a0023904

Juczyński, Z. (1999). Narzędzia pomiaru w psychologii zdrowia [Measurement instruments in health psychology]. Przeglad Psychologiczny, 42(4), 43-56.

Krizan, Z., \& Johar, O. (2012). Envy divides the two faces of narcissism. Journal of Personality, 80(5), 1415-1451. doi:10.1111/j.1467-6494. $2012.00767 . \mathrm{x}$

Lange, J., \& Crusius, J. (2015). Dispositional envy revisited: Unraveling the motivational dynamics of benign and malicious envy. Personality \& Social Psychology Bulletin, 41(2), 284-294. doi:10.1177/0146167214564959

Lerner, M. J. (1980). The belief in a just world: A fundamental delusion. New York: Plenum Press.

Lyubomirsky, S., \& Nolen-Hoeksema, S. (1993). Self-perpetuating properties of dysphoric rumination. Journal of Personality and Social Psychology, 65(2), 339-349.

Martin, L. L., \& Tesser, A. (1996). Some ruminative thoughts. In R. S. J. Wyer (Ed.), Ruminative thoughts (pp. 1-47). Hillsdale, NJ, England: Lawrence Erlbaum Associates, Inc.

McCullough, M. E., Bono, G., \& Root, L. M. (2007). Rumination, emotion, and forgiveness: Three longitudinal studies. Journal of Personality and Social Psychology, 92(3), 490-505. doi:10.1037/ 0022-3514.92.3.490

Miceli, M., \& Castelfranchi, C. (2007). The envious mind. Cognition \& Emotion, 21(3), 449479. doi:10.1080/02699930600814735

Milfont, T. L., \& Gouveia, V. V. (2009). A capital sin: Dispositional envy and its relations to wellbeing. Interamerican Journal of Psychology, 43, 547-551.

Nolen-Hoeksema, S. (1991). Responses to depression and their effects on the duration of depressive episodes. Journal of Abnormal Psychology, 100(4), 569-582. doi:10.1037/0021-843X.100. 4.569

Nolen-Hoeksema, S., Wisco, B. E., \& Lyubomirsky, S. (2008). Rethinking rumination. Perspectives on Psychological Science, 3(5), 400-424. doi:10.1111/j.1745-6924.2008.00088.x

Parrott, W. G. (1991). The emotional experience of envy and jealousy. In P. Salovey (Ed.), The 
psychology of jealousy and envy (pp. 3-30). New York, NY, US: Guilford Press.

Parrott, W. G., \& Smith, R. H. (1993). Distinguishing the experiences of envy and jealousy. Journal of Personality and Social Psychology, 64(6), 906-920. doi:10.1037/0022-3514.64. 6.906

Piskorz, J., \& Piskorz, Z. (2009). Situational determinants of envy and Schadenfreude. Polish Psychological Bulletin, 40(3), 137-144. doi:10.2478/ s10059-009-0030-2

Ready, R. E., Vaidya, J. G., Watson, D., Latzman, R. D., Koffel, E. A., \& Clark, L. A. (2011). Agegroup differences in facets of positive and negative affect. Aging \& Mental Health, 15(6), 784795. doi:10.1080/13607863.2011.562184

Sawada, M., \& Arai, K. (2002). Dispositional envy, domain importance, and obtainability of desired objects: Selection of strategies for coping with envy. Japanese Journal of Educational Psychology, 50(2), 246-256.

Sawada, M., \& Hayama, D. (2012). Dispositional vengance and anger on Schadenfreude. Psychological Reports, 111(1), 322-334. doi:10.2466/ 16.07.21.PR0.111.4.322-334

Scheier, M. F., Carver, C. S., \& Bridges, M. W. (1994). Distinguishing optimism from neuroticism (and trait anxiety, self-mastery, and selfesteem): A reevaluation of the Life Orientation Test. Journal of Personality and Social Psychology, 67(6), 1063-1078. doi:10.1037/00223514.67 .6 .1063

Smith, R. H., \& Kim, S. H. (2007). Comprehending envy. Psychological Bulletin, 133(1), 46-64. doi:10.1037/0033-2909.133.1.46
Smith, R. H., Parrott, W. G., Diener, E. F., Hoyle, R. H., \& Kim, S. H. (1999). Dispositional envy. Personality and Social Psychology Bulletin, 25(8), 1007-1020. doi:10.1177/ 01461672992511008

Smith, R. H., Parrott, W. G., Ozer, D., \& Moniz, A. (1994). Subjective injustice and inferiority as predictors of hostile and depressive feelings in envy. Personality and Social Psychology Bulletin, 20(6), 705-711.

Szabó, N., Dubas, J. S., \& van Aken, M. A. G. (2014). Jealousy in firstborn toddlers within the context of the primary family triad. Social Development, 23(2), 325-339. doi:10.1111/sode.12039

Uphill, M. A., \& Dray, K. (2009). Giving yourself a good beating: Appraisal, attribution, rumination, and counterfactual thinking. Journal of Sports Science \& Medicine, 8(CSSI3), 5-12.

Van de Ven, N., Hoogland, C. E., Smith, R. H., van Dijk, W. W., Breugelmans, S. M., \& Zeelenberg, M. (2015). When envy leads to Schadenfreude. Cognition \& Emotion, 29(6), 1007-1025. doi:10.1080/02699931.2014.961903

Van de Ven, N., \& Zeelenberg, M. (2015). On the counterfactual nature of envy: "It could have been me". Cognition \& Emotion, 29(6), 954971. doi:10.1080/02699931.2014.957657

Van de Ven, N., Zeelenberg, M., \& Pieters, R. (2009). Leveling up and down: The experiences of benign and malicious envy. Emotion (Washington, D.C.), 9(3), 419-429. doi:10.1037/a0015669

Vecchio, R. (2005). Explorations in employee envy: Feeling envious and feeling envied. Cognition \& Emotion, 19(1), 69-81. doi:10.1080/ 02699930441000148

\title{
CHCEM TO, ČO MÁŠ TY A NECHCEM, ABY SI TO TY MAL
}

\author{
A. B łachnio, A. Przepiorka
}

Súhrn: Závist' je emócia, ktorú pocit'ujeme voči niekomu inému, ak má niečo, čo chceme mat' aj my, alebo nechceme, aby to ten iný mal. Niektorí autori rozlišujú medzi zákernými a neškodnými formami závisti. Hlavným ciel'om nášho výskumu bolo zistit', či existuje vzt'ah medzi závist'ou a sebaúctou, škodoradost’ou, optimizmom a rumináciou. Ďalším ciel’om bolo overit’ validitu a reliabilitu pol'skej verzie Dispositional Envy Scale (DES), ktorá sleduje sklon k závisti, blížiacej sa až k zákernej závisti. Výskumu sa zúčastnilo 1221 l'udí vo veku $14-69$ rokov. DES bola preložená do pol’štiny metódou spätného prekladu. 8-položková jednofaktorová DES vykazuje dobré psychometrické vlastnosti, hodnota Cronbachovej alfy je .86. Podl'a výsledkov je závist' v pozitívnom vzt'ahu so škodoradost'ou a rumináciou a v negatívnom vzt'ahu s vekom, sebaúctou a optimizmom. 